\title{
Vitalism and the resistance to experimentation on life in the eighteenth century
}

\author{
Charles T. Wolfe \\ Department of Philosophy and Moral Sciences, University of Ghent \\ Charles.Wolfe@ugent.be
}

\begin{abstract}
There is a familiar opposition between a 'Scientific Revolution' ethos and practice of experimentation, including experimentation on life, and a 'vitalist' reaction to this outlook. The former is often allied with different forms of mechanism - if all of Nature obeys mechanical laws, including living bodies, 'iatromechanism' should encounter no obstructions in investigating the particularities of animal-machines - or with more chimiatric theories of life and matter, as in the 'Oxford Physiologists'. The latter reaction also comes in different, perhaps irreducibly heterogeneous forms, ranging from metaphysical and ethical objections to the destruction of life, as in Margaret Cavendish, to more epistemological objections against the usage of instruments, the 'anatomical' outlook and experimentation, e.g. in Locke and Sydenham. But I will mainly focus on a third anti-interventionist argument, which I call 'vitalist' since it is often articulated in the writings of the so-called Montpellier Vitalists, including their medical articles for the Encyclopédie. The vitalist argument against experimentation on life is subtly different from the metaphysical, ethical and epistemological arguments, although at times it may borrow from any of them. It expresses a Hippocratic sensibility - understood as an artifact of early modernity, not as some atemporal trait of medical thought - in which Life resists the experimenter, or conversely, for the experimenter to grasp something about Life, it will have to be without torturing or radically intervening in it. I suggest that this view does not have to imply that Nature is something mysterious or sacred; nor does the vitalist have to attack experimentation on life in the name of some 'vital force' - which makes it less surprising to find a vivisectionist like Claude Bernard sounding so close to the vitalists.
\end{abstract}

Keywords: vitalism, experiment, Ménuret de Chambaud, Enlightenment

In order to study the phenomena pertaining to living beings and discover the laws that govern them, it is not necessary to know the essence of life itself. -

Claude Bernard ${ }^{1}$

\section{Introduction}

\footnotetext{
${ }^{1}$ Bernard 1869, p. 194 (unless otherwise indicated all translations are mine).
} 
Early modern scientific practice, from the Scientific Revolution to the Enlightenment - to use familiar terms designating complex entities which successive generations have revealed to be constructs at the service of various programs - seems to be overwhelmingly associated with a culture of experiment, an 'experimental' sensibility, and most generally, the proclamation of the importance and indeed superiority of 'experimental philosophy'. Representative figures such as Bacon and Descartes proclaim in well-known statements that technological progress enables us to become "the masters and possessors of Nature," or, closer to the life sciences with which we shall be concerned here, that "Founding a real model of the world . . . cannot be done without dissecting and anatomizing the world," whether or not Bacon really advocated the 'torture of nature' in his rhetoric of experimental inquiry. ${ }^{2}$ If we then ask where the life sciences fit in this confident discourse cum practice of experiment, the situation is suddenly less obvious, and at the very least seems to be marked by a tension.

On the one hand, this experimentalist narrative easily includes the 'Oxford physiologists' such as William Harvey and Richard Lower, who were nothing if not vivisectionnistes heureux, especially when one considers Lower's grisly transfusion experiments on dogs. ${ }^{3}$ Granted, even such an avid dissecter as Harvey introduces nuances, as in Chapter VI of De motu cordis, when he criticizes the practice of human dissection for dealing mainly with dead organs and being non-generalisable, in contrast to his own practice of comparative animal dissection (chicks, deer, shrimp, and so on). And in a different, more interpretive vein, Alan Salter's recent work on Harvey has pointed to his stress on unmediated ocular observation as a way of inquiry, in his ligature experiments (Salter and Wolfe 2009, Salter 2010; see also Dear 2006).

But on the other hand, if we focus specifically on experimentation or intervention on living beings, cracks in the edifice appear more clearly. We find a variety of objections to experimentation (whether dissection or vivisection), which for the sake of brevity I shall divide into three general kinds: (i) ethical (including religious variants), (ii) methodological and (iii) ontological, following a roughly chronological order. The vitalist position on experimentation on living beings, which I shall be concerned with here (that is, the positions taken by the members of the Montpellier Medical Faculty in the second half of the eighteenth century, who became self-identified as 'vitalists' by the end of the century; representative figures include Bordeu, Fouquet, Ménuret, and Barthez, but in this essay I focus especially on Ménuret given his level of interest in our topic), combines or alternates

\footnotetext{
${ }^{2}$ Respectively, Descartes, Discourse on Method, part VI, AT VI, 62; Bacon, Novum Organum, I, § 124, in Bacon (1857-1874), I, p. 218 / IV, p. 110. On the phrase 'the torture of nature' and how not to overread it, see Pesic 1999.

${ }^{3}$ Albrecht von Haller, who is a key background figure in our story, speaks in favour of Harvey's experimentation although he acknowledges that he has done violence to Nature ("forced Nature to answer") in a 1775 review of Senebier's Art d'observer in the Göttingische Gelehrte Anzeigen, p. 419, cit in. Steinke 2005, p. 168, note 57; I thank Hubert Steinke for this reference. For further discussion of Harvey on vivisection see Anita Guerrini's essay in this volume.
} 
between methodological and ontological objections; but in addition, contrary to what we might expect, it is not always hostile to experimentation. In the next section I discuss these various types of objection, before turning to vitalism proper for the remainder of the essay.

What we will find is that (a) most of the Montpellier vitalists support at least the practice of post mortem dissection of humans and animals and (b) that when they polemicize against experiment, it is because they think we cannot know Life through intervention - which is a broad, amorphous category that can encompass actual vivisection at one end of the spectrum but also other interventions including on corpses, in a neoHippocratic motif which opposes observation (good) to experiment (sometimes bad). As I discuss below, some members of this group are more experiment-friendly than others (Ménuret is more so than Fouquet, for instance); but even considered individually rather than comparatively, their views are not univocal. Yet nowhere in their writings do we find any trace of the idea that living beings cannot be experimented on because they possess some unique, supernatural vital force. But let me turn to the objections against experimentation.

\section{Preliminaries on the seventeenth century}

The ethical opposition to vivisection is most familiar to us, such as the naturalist John Ray's declaration that "the torture of animals is no part of philosophy," or Henry More's statement to Descartes that his theory of animal-machines was "deadly and murderous." 4 Indeed, some early modern experimentalists seem to have worried about suffering to the extent of fearing that they were sinners (Maehle and Tröhler 1987, Guerrini 1989). A variant on this seems to be motivated more by Weltanschauung-type differences, as in Lady Margaret Cavendish's reflections on our inability to judge the world of animals and the violence we do to them, including in gendered terms. In her early work The Worlds Olio (1655), her entry "Of Birds" identifies Cavendish as a woman with the birds. In her autobiography, she writes: "I am tender natured, for it troubles my Conscience to kill a fly, and the groans of a dying Beast strike my Soul." ${ }^{5}$ Unsurprisingly, Cavendish was also strongly opposed to the Experimental Philosophy, ridiculing figures such as Robert Hooke in somewhat gendered terms, as "Boys that play with watry Bubbles, or fling Dust into each others Eyes, or make a Hobby-horse of Snow," and describing the "artificial" effects produced by experimentation upon natural objects as "Hermaphroditical, that is, mixt

\footnotetext{
${ }^{4}$ Ray, "De animalibus in genere" (1693), translated in Raven 1942, p. 375; see the discussion in Guerrini 1989, p. 399. More, letter to Descartes of December 1648 (AT V, 243; Webster 1969, Semler 2010).

5 "A true Relation of my Birth, Breeding, and Life," in Cavendish 1656, p. 388; discussed in Semler 2010. Some of this is 'affect' - she wrote famous poems on 'the hunting of the stag' and her horror of it - but it is also something else. For further discussion of Cavendish including the relation between her philosophy of nature, her conceptions of gender, and her attitude towards the Experimental Philosophy, see Sarasohn 1984 and Sarasohn 2010.
} 
Figures, partly Artificial, and partly Natural"; these "hermaphroditical" figures are monstrous, such as a "beautiful young Lady" depicted in the gaze of the experimenter: "if the Picture of a young beautiful Lady should be drawn according to the representation of the Microscope, ... . it would be so far from being like her, as it would not be like a humane face, but rather a Monster, then a picture of Nature." ${ }^{6}$

Others, such as Robert Boyle, dismiss the issue rather quickly, with the exception of human dissection. Despite his vivisectionist practice, Boyle, in this a good Christian anthropocentrist, is explicit that human dissection is a violation of both divine and human law: "since it were too barbarous, and too great a violation of the Laws, not only of Divinity but Humanity, to dissect humane Bodies alive, as did Herophilus and Erasistratus, who (as I finde in some of the Ancients) obtain'd of Kings the Bodies of Malefactors for that purpose, and scrupled not to destroy Man to know him," but since there is no other way to learn about various parts of anatomy (we might say physiology), since many things including the motion of the Blood "cannot be discover'd in a dead dissected Body," we need to perform animal vivisections. ${ }^{7}$

In contrast both to Cavendish's concerns with the "groans of a dying Beast" and to Boyle's relative indifference, thinkers such as John Locke and Thomas Sydenham, in their reflections on anatomy, challenge the authority of disembodied instrument-knowledge and experimentation (Walmsley 2008; Salter and Wolfe 2009). This is one big step closer to the central claim of the vitalists (and Diderot) which I shall be investigating: that vivisection, inasmuch as it is a type of intervention, renders the evidence warped or unusable, or its more epistemological variant, that we will fail to understand something basic and essential about living beings if we treat them as analyzable, decomposable, dissectable sets of parts (the latter claim, depending on how strong it is, can become an ontological claim about Life itself). This is the vitalist claim (even if the representative figures discussed here do not hold a constant, monolithic version of it); it is frequently expressed with various references to the Hippocratic tradition - and I mean this as an artifact of early modernity, not as an atemporal trait of medical thought - in which Life resists the experimenter, or conversely, if the experimenter wants to grasp something about Life it will have to be without torturing or at least radically intervening in it.

The figures whose views on vivisection I shall be concerned with here - the Montpellier vitalists - do not speak of the "torture chamber of Nature" as Goethe did. ${ }^{8}$ They do not, overall, invoke a hidden interiority of Nature, which will not "reveal its secrets under torture." ${ }^{9}$ To reject or at least criticize vivisection, i.e. experimentation on live animals, or -

\footnotetext{
${ }^{6}$ Cavendish 1666, § 3, "Of Micrography...," pp. 11, 8, 9-10; on the first passages see Ait-Touati 2011, ch. 5 and Sarasohn 2010, Introduction. Medical experiments were frequently termed "artificial observations" - in valueneutral terms, unlike Cavendish's (e.g. Roederer 1753/1765, Preface).

${ }^{7}$ Usefulness of Natural Philosophy 1663, in Works I, p. 465, partly cited in Maehle and Tröhler 1987, p. 20.

${ }^{8}$ Goethe 1988, p. 309, cited and discussed in Gilad 2010, III, § 7.

${ }^{9}$ Goethe 1988, p. 307.
} 
depending on the context - observations based on post mortem anatomy, because they warp or denature the essence or uniquely 'vital' character of the subjects under examination, does not necessarily imply that living Nature is something mysterious or sacred. (I leave open for now the question of whether it is in the name of a concept of Life that certain kinds of scientific practices are proscribed, as argued e.g. in Merchant 1980 and Kass 1999; but most of the textual evidence we shall survey argues against this.)

This closely parallels the way few, if any of these physicians ever invoke a "vital force" in support of their critiques of iatromechanism (which are also, symmetrically, critiques of the un-naturalism of Stahlian animism; Rey 2000, Wolfe and Terada 2008). Less Romantic-sounding than the "torture of Nature," the vitalists are concerned with how a certain type of 'analytic method', a method of decomposition, kills the animal, not so much as a moral problem but as a problem for the investigator. ${ }^{10}$ Their concern is that the usage of concepts which are appropriate to inanimate nature prevents us from grasping the laws of life - or at least anything regular and able to serve as a feature or definition of life. As I discuss in closing, the irony is that that great vivisectionist, Claude Bernard, worries about just these issues and makes very similar statements - which perhaps is less surprising if we remember his complex relation to the idea of vitalism.

\section{The Montpellier School}

Who are the Montpellier vitalists? A group of physicians and professors of medicine in the second half of the eighteenth century including notably Théophile de Bordeu, JeanJoseph Ménuret de Chambaud, Louis de La Caze, François Boissier de Sauvages de la Croix (known as Sauvages), Henri Fouquet, Paul-Joseph Barthez. The term 'vitalist' is self-applied by the late 1790s, by Charles-Louis Dumas, the Dean of the Montpellier medical faculty in the early nineteenth century. The view favoring observation and criticizing experimentation is extended into the nineteenth century by Jacques Lordat, Barthez's protégé and the Chair in Anatomy at Montpellier in the next generation, after Dumas. ${ }^{11}$ In what follows I shall focus in particular on Ménuret and Fouquet for they have the most to say on the topic of vivisection, dissection, and experimentation on living and dead animals overall.

Henri Fouquet (1727-1806), a professor of clinical medicine at Montpellier and the author of entries such as "Sensibilité" and "Secrétion" in the Encyclopédie as well as a noted

\footnotetext{
${ }^{10}$ When Barthez adds a discussion of Condillac's analytic method to his Nouveaux élémens de la science de I'homme (Barthez 1858, I, pp. 20-21), he does not seem to notice that logical decomposition of entities and experiences into their component parts might conflict with a strong organismic view.

${ }^{11}$ There is no monolithic 'vitalist position' on animal or human experimentation in other linguistic, scientific and cultural contexts; so, for instance, early nineteenth-century figures like Blumenbach or Wolff, because they work on much smaller organisms in their focus on reproduction, do not perform vivisections overall (I thank Joan Steigerwald for this point).
} 
Discours sur la Clinique and an Essai sur le Pouls, does end his article "Sensibilité" by stating with some rhetorical flourish that we will never know the depths of Nature:

the best experiments are still insufficient to advance our knowledge of a subject, the delicate objects of which are denatured or disappear under the hand that seeks to manipulate them. . .. As Seneca says, 'so many things dwell in the shadows of an impenetrable secret ...' We must therefore be content with a few passing forms which Nature, like Proteus who cannot be forced, sometimes allows us to grasp... (Enc. XV, p. 52a).

But nevertheless, aside from this rather Romantic or naturphilosophisch moment, the vitalists never make claims about living beings possessing a kind of hidden inwardness which the evil experimenter cannot grasp with his alienating instruments. They claim, after all, to be empiricists, but of a particular sort, given to emphasizing observation, praising Hippocrates (and the 'English Hippocrates', Sydenham), and downplaying the merits of experimentation qua intervention. Indeed, as mentioned above, Locke and Sydenham themselves argued that there is something about living bodies which the investigator will miss if dissection and intervention are practice, a view which goes back to the ancient empirikoi and their suspicion of general medical theory and intervention (von Staden 1975, p. 187). In his article "Observation," Ménuret quotes the empiricist slogan Nihil est in intellectu quod non fuerit in sensu (there is nothing in the intellect which was not first in the senses, Enc. XI, p. 314b), and explicitly uses the term "empirisme" which was quite rare at the time (p. 315b). ${ }^{12}$ We can describe this as a 'medical empiricism' ${ }^{13}$

What then is the problem with intervention? Fouquet explicitly uses the term 'vivisection' in "Sensibilité" (but with a slight typographical error, the consequence of which is that the searchable Encyclopédie on ARTFL produces no results for a search on the word 'vivisection'). The context is Bordeu's critique of Haller, which Fouquet presents approvingly. Fouquet comments:

In his vivi-sections Bianchi has noticed the absence and return of sensitivity (sensibilité) in one part, within a few moments. The fear which animals, like humans can feel, has a singular effect on the activity of this sensitivity .... But who knows how far the effects of this feeling (passion) can go, beneath the knife of a dissector (Enc. XV, p. 51b; the article goes on to refer to Bordeu's thesis on contractility and sensitivity). ${ }^{14}$

\footnotetext{
${ }^{12}$ Barthez, the 'leader' of and most influential spokesperson for the Montpellier vitalists in the late eighteenth century, proudly layers the revised version of his magnum opus with empiricist philosophical references (to Bacon, Locke, Hume and Condillac in particular), which however tend to render his point murkier than it would have been otherwise (see e.g. Barthez 1806, pp. 10-11, note 1). In an undated set of lectures from the late 1760s he opposes what he calls "reasoned empiricism" to Haller's interventionism ("Cours de thérapeutique," ms., cit. in Williams 2003, p. 258).

${ }^{13}$ On the category of 'medical empiricism' and how we should rethink it, see my remarks in Wolfe and Gal, eds., 2010, especially p. p. 333f.

${ }^{14}$ The Bianchi referred to here is probably Giovanni Battista Bianchi, the author of Historia hepatica $\left(3^{\mathrm{d}}\right.$ revised edition, Geneva, 1725). In his article "Anatomie" for the Supplément (I, 1776, 399a-414b), Haller describes Bianchi as the author of several anatomical works - on the liver, the muscles of the bladder, and one containing
} 
This means the word is being used in a recognizable significance, to mean medico-surgical intervention on living animals, in 1765 (while Bloch and Wartburg's Dictionnaire étymologique only dates it back to 1832; of course, the Oxford English Dictionary goes as far back as a 1707 quote from Sir Hans Sloane, describing the motion of fluids in animal bodies; Haller uses it in a 1751 letter to Georg Thomas von Asch. ${ }^{15}$

Elizabeth Williams has noted that "While some experimental vivisections were undertaken in mid-century Montpellier, chiefly in response to Haller's claim to have differentiated clearly between the "sensibility" of nerves and the "irritability" of muscles, animal experimentation had, overall, little place in Montpellier" (something documented by Hubert Steinke in his impressive work on Haller $^{16}$ ). She adds that "Not only were the requisite facilities and collections lacking in Montpellier, but, chiefly, the conviction that much useful was to be gained from such methods" (Williams 2008, p. 610). I want to suggest something different - not opposed to Williams' point, but taking a very different angle to emphasize why the montpelliérains might not have been vivisectionists. And even this wellknown fact, which feeds into and is supported by the overall vision of an opposition between the Paris Faculty - interventionist, clinical, reductionist, pro-vivisection - and the Montpellier Faculty, with its so-called 'philosophical medicine' - expectant, observational, holistic - is subject to some revision, as I shall show. ${ }^{17}$

\section{Ménuret}

Let us turn to Ménuret. Jean-Joseph Ménuret de Chambaud (1733-1815) was born in Montélimar and came to Montpellier to do his doctorate in medicine, with a thesis on biological generation, arguing for epigenesis contra preexistence (De Generatione Dissertatione Physiologica, defended in 1757). ${ }^{18}$ The story of how he came to be a major medical collaborator of the Encyclopédie has been well studied, although for a long time people did not notice his articles as such, not least because they failed to identify a large number of articles as being Ménuret's. ${ }^{19}$ Ménuret was introduced to the editors by the

\footnotetext{
"hardly credible" sketches of human embryos; the latter interest seems to have led Bianchi to investigate monsters. Bianchi's debates with Morgagni, Haller adds, were not in his favor.

${ }^{15}$ Sloane, A Voyage to the Islands of Madera, Barbados... (1707), in Oxford English Dictionary, s.v. 'Vivisection'; Haller, cit. in Maehle and Tröhler 1987, p. 39, n. 13.

${ }^{16}$ On experiments undertaken in Montpellier in response to Haller's claims, see Steinke 2005, pp. 134-135.

${ }^{17}$ This standard oppositional view has had a major effect on the exclusion of the Montpellier 'school' from mainstream history of medicine: witness the almost strident polemic in Joseph Schiller's history of physiology (Schiller 1978) against these misty-eyed holists, in favor of proper mechanists like Descartes, Bernard and Lamarck.

${ }^{18}$ I am drawing mainly on Rey 2000, extended by Boury 2004.

${ }^{19}$ It was chiefly Roselyne Rey's 1987 thesis, published posthumously in 2000, that put them on the map (Jacques Roger and Jacques Proust had called attention to Ménuret's contribution earlier). In Rey's view, if we set aside the case of the 'polygraph' Chevalier de Jaucourt, Ménuret's contribution to the medical articles in
} 
chemist Gabriel-François Venel, who brought him in to replace Arnulphe d'Aumont, another montpelliérain. He authored over one hundred articles for the Encyclopédie, initially signed "Ménuret," then " $M$ " or " $m$ " after volume IX; these include key programmatic pieces such as "CEconomie Animale," "Inflammation," "Mort" and "Observation." His later career is less well known: like Bordeu, he was a physician at the Hôpital de la Charité, before leaving Paris around 1761 for Montélimar where he was based for almost twenty years, publishing works such as Le nouveau traité du pouls (1768), and focusing on the role of climate and the study of epidemics; he also combined the two in what he called 'medical topography', in which we can still see a Hippocratic paternity via Sydenham, as Ménuret discusses in the article "Observation" (pp. 319-320). He also took a position in favor of inoculation like the other encyclopédistes (see his Avis aux mères sur la petite vérole et sur la rougeole of 1768). In 1784 he returned to Paris, and wrote amongst other works an essay on medical reform (Essai pour former de bons médecins, 1791). Ménuret was favorably disposed towards the Revolution as a trend that might favor reform in public health and in medical practice, but fell from favor and moved to Hamburg, following General Dumouriez; he died in Paris in 1815.

Anne Vila notes that Ménuret de Chambaud's article "Observation" (along with its shorter companion piece "Observateur," both from the 1765 'crop' of the Encyclopédie) operates on a broader canvas than just medicine per se (Vila 1998, p. 56); they seem to be laying out a program for natural philosophy overall, defined in opposition to experimental natural philosophy. Indeed, "Observation" begins by discussing how we attend to Nature and natural entities ("les objets qu'offre la nature," Enc. XI, p. 313b) and further on describes observation as "the foundation of all the sciences" (p. 314a). The article, as its title partly indicates, functions on the basis of a basic opposition between observation and experiment, with a privileging of observation which is characteristic of the vitalists but also crops up in more unexpected places in the Encyclopédie: thus Steinke notes that D'Alembert's article "Expérimental" distinguishes between the two bases of 'experimental physic', observation and experiment, and points to the first as more "fundamental" ("profonde"). It is excessive, however, to claim that observation trumps experiment throughout the eighteenth century in France, as Salomon-Bayet does (Salomon-Bayet 1978, p. 337). What is noteworthy in Ménuret's article, though, is that quite soon he emphasizes that the distinction between observation and experiment is of special relevance to living beings:

As we move from the physics of simple bodies to that of organized bodies, we see the rights of experiment (expérience) decrease, and the rule and usefulness of observation increase; the shape, bearing, location, structure - in a word, the anatomy of plants of animals, the different stages through which they pass, their motions, functions and life, etc., have only been seen by the observer-naturalist (Enc. XI, p. 315a).

the Encyclopédie, from volume VIII onwards (excluding anatomy, surgery, and the material medica) is the largest, most homogeneous set of texts in that work (Rey 2000, p. 72). 
And he adds a bit further on - blurring the human/animal divide or on the contrary reemphasizing an old sense in which the uniqueness of living beings is ultimately a way of defending anthropocentrism or the uniqueness of humans:

Man, however we consider him, is least well suited to being a subject of experiment; he is the most suitable, noblest and most interesting object of observation, and it is by observation alone that progress can be made in the sciences of man (qui le regardent); experiment here is often worse than useless (ibid.).

At first the distinction between observation and experiment in Ménuret's article is a bit confusing, because animal dissections are not considered experiments ("expériences") since they simply extend and enhance our powers of observation. However, once you intervene, decompose, mix an animal's blood with another liquid, then you are experimenting (p. 314a; the reference here is probably to Lower's transfusion experiments in the 1660s, in which he gradually replaced the blood through a dog's jugular vein, with fluids such as ... beer and wine: "The Heart-beat, meanwhile, became only slowly more feeble, so that practically the whole of the blood was replaced by beer before life was replaced by death" [Lower 1669/1932, p. 67]). Similarly, anatomical observations on cadavers ("observations anatomiques cadavériques," Ménuret, op. cit., p. 317a) are still ... observations.

Ménuret does not have a categorical, a priori or otherwise normative objection to dissection; he has an epistemological critique (and even that term is a bit too strong) of experimental phenomena that have been arbitrarily "decomposed and combined," giving rise to conditions "far different from those present in nature" (p. 313b). This reads like a more subtle version of the points in Louis de La Caze's 1755 Idée de l'homme physique et moral (to which Bordeu - along with Venel - was forced to collaborate in conditions he described as quite unpleasant, having to produce ideas for a madman who thought he was producing a work of genius): 'observation' means "what can be observed on a healthy or sick body," whereas 'experiment' means "whatever can be observed of a dead body" (La Caze 1755, p. 9); an example of what not to do is Boerhaave's "useless experimentation" (ibid., pp. 47-48, 66). Obviously, such definitions are not standard ones for the time. ${ }^{20}$

The distinction or 'polarization' between anatomy and physiology is less relevant here than we might expect, ${ }^{21}$ and it is not always drawn along traditional lines, such as when

\footnotetext{
${ }^{20}$ It is not the intent of the present essay to seek to define the place of the vitalist understanding of 'observation versus experiment' in some kind of history of scientific observation, if such a history were possible. But it seems obvious that in Ménuret and allied figures, observation has become an "epistemic category," to use the (artificially strict?) language in Daston 2011.

${ }^{21}$ Andrew Cunningham has suggested - in a somewhat confusing analysis of the development of anatomy and physiology as disciplines - that physiologists before the nineteenth century considered vivisection to be part of anatomy, not physiology; "What Haller does not do when investigating function is start from experiment on the live animal. Rather, he starts from anatomy to establish structure and the properties of the parts, and only then has recourse to vivisectional experiment to clarify function" (Cunningham 2002, p. 656). In fact, from Galen,
} 
Ménuret classifies different parts of medicine as different types of observation: "Anatomy results from simple observations of shape, location etc. of the parts comprising the human body; the observation of the functions produced by the movement or life of these welldisposed parts constitutes the historical part of Physiology and the semeiotics of health, from which theoretical Physiology is ... derived" ("Observation," Enc. XI, p. 316b). But Ménuret emphasizes that when the experimenter - anatomist or physiologist - dissolves blood freshly drawn from an animal, using other liquids, the knowledge she derives regarding the resulting mixture "is no longer the fruit of pure observation; . . knowledge acquired by this means is quite mediocre and imperfect" (p. 314a). As to "cadaverous observations," Ménuret takes a middle road - with a militant Enlightenment twist:

even if I've said that such observations have, so far, not shed much light on the diagnosis of diseases, I did not claim that they were absolutely useless. Even less did I think that one could never perfect such observations, and make them more useful: I quite willingly concur with those who approve of a law that would mandate corpses being handed over to priests, only after the Anatomists are done with them. An improved knowledge of diseases would not be the only benefit resulting from this (p. 320b).

There is a curious tension in the article, which displays, not the contradictions of vitalism for these are not logical contradictions but tensions in between different commitments - but the difficulty of keeping them together. Namely, Fouquet is much more strongly opposed to a lot of this, as we shall see, and Bordeu is much more indifferent. Ménuret, who is very much 'materialism-friendly' overall (Wolfe and Terada 2008), here seems to waver. On the one hand, corpses should be handed over to anatomists before they get to the priests. On the other hand,

If we based instructions for a cure on the observation of corpses, our reasoning would be faulty, and our practice even worse. In order to establish something certain, we would have had to open up fifty people suffering from the same illness, who died at different times from other causes; one could then see the progress of the disease and the disturbances it causes, or which gave rise to it - an almost impossible [sort of] observation (Enc. XI, p. 318a).

Ménuret makes the complementary point that therapeutic conceptions derived from the observation of corpses are also often false because they are badly done: a patient who had complained of sharp pains in his side dies, he is autopsied, his chest is examined, and nothing is found; but if he had been examined lower down, the liver or lower part of the diaphragm could be inflamed (ibid.). However, he grants that post mortem dissections can be useful-paradoxically - when they reveal no sign of illness, no cause of death: because

\footnotetext{
Vesalius and especially Harvey to Haller (who famously described physiology as "anatomy animated"), Bordeu and here Ménuret, examples abound of anatomical analyses which include explicit functional explanations where anatomy speaks of usus, of the performance of an organ, of its action; vitalist discussions of the "animal economy" seem almost deliberately to blur the divide between these traditional disciplines. A different way of stressing the distinction between anatomy and physiology would emphasize that the more the investigator starts from physiology, the more she is a kind of a 'spontaneous holist', with a different standpoint from that of the anatomist.
} 
this can demonstrate that the disease was in the nerves. Barthez, in a lecture course of the 1760s, also takes we might call a critical empiricist stance towards dissections, by which I mean that he does not take an a priori stance denying the possibility that they could reveal anything about disease, death or vitality. Rather, he notes that such analyses can only tell us about the final state of the disease ("Cours de thérapeutique," undated ms., late 1760s, cit. in Williams 2003, p. 258).

But to return to the 'dialectic' of Ménuret's position, we should notice that despite his criticisms of what thirty years later would be called pathological anatomy (itself practiced and theorized by figures such as Xavier-Marie Bichat who were themselves accused of being 'vitalists'), Ménuret also sometimes turns back to his 'hard Enlightenment' standpoint, mocking the ancient "superstitions and prejudices" that prevented doctors from having contact with corpses and referring admiringly to the boldness of Herophilus and Erasistratus:

Herophilus and Erasistratus are considered to be the first who dared to challenge prejudice by dissecting not merely human corpses, but living criminals, which philosophically minded princes would hand over to them, for the sake of the public good. As soon as this first step was taken, the physicians who came after them continued their work, and enlightened kings supported these attempts with real permissions and the greatest honors. From this came rapid progress in Anatomy, and frequent discoveries (Enc. XI, p. 317a).

More surprising is that Ménuret goes on to applaud actual human vivisection:

This kind of observation would undoubtedly be more useful if, like Herophilus, we examined the structure of the living body. Reasoned or physiological anatomy would gain much regarding the use and necessity of the various parts. If this project were carried out, we should not view it as barbarous or inhuman; so many individuals who deserve, due to their crimes, to end their lives on the gallows in the cruelest torment, could care less about being placed in the hands of an anatomist, who in turn would not see his role as executioner as anything dishonorable, but rather as a means to gain further knowledge and be useful to the public: crime is the shame, not the gallows. .. . There are cases in which it is expedient for a man to die for the public, and humanity of course. . A man compared with all others is nothing; a criminal is less than nothing (ibid., p. 317b).

This rather utilitarian (and chilling) praise for vivisection is quite unique amongst the montpelliérains. The praise for the Alexandrians could be by Diderot, or Claude Bernard. But what is odd is that all of this - not the apologia for experimenting on criminals, but the praise of human vivisection - is more or less seamlessly fused with the Hippocratic, observational theme.

\section{An intermezzo on Diderot}

Is this inconstancy, wavering or a basic duality in the thought of theses figures, when considering the pros and cons of experimentation on living bodies? Interestingly, we find much the same tension in the work of Diderot, a thinker who was very influenced by the vitalists while at the same time asserting a thoroughgoing materialism (contrary to naïve, 
historically imprecise oppositions between materialism and vitalism that are still found in a variety of major reference works) ${ }^{22}$; Diderot famously made Bordeu a central character in his unpublished masterpiece Le Rêve de D'Alembert (written 1769). He wavers, not so much regarding the ethical legitimacy of experimentation and vivisection, but regarding their ontological legitimacy. On the one hand, he argues in favor of the dissection of corpses (and uses the same image as Ménuret: "in a well-run society, priests should only receive cadavers from the hands of the anatomists, and there should be a law forbidding the burial of a body prior to its dissection" ${ }^{23}$ ); on the other hand, displaying what is sometimes referred to as the vitalistic dimension of his materialism, he worries about the intrinsic features of Life: "without life, there is no distinction between the man and the corpse" (Éléments de physiologie, in Diderot 1975-, XVII, p. 310).

As a materialist, a promoter of scientific discovery, a 'naturalist' in the sense of a thinker for whom all knowledge about ourselves should be integrated with the state of our knowledge about the natural world, it makes sense that Diderot praises Herophilus, Erasistratus and Celsus, and experimentation on humans in general (unlike, say, Riolan, for whom the Alexandrian physicians experimented on humans because they were pagans, since all good religion rejects doing $\mathrm{so}^{24}$ ). But in the article "Histoire naturelle" (and its companion piece, "Cabinet d'histoire naturelle") he worries that "animal corpses, their remains," are but a "feeble representation of living animals" (Enc. VIII, 229b, discussed in Wolfe 2009). And closer to the focus on the study of Nature overall that Anne Vila detected in Ménuret's article "Observation," Diderot adds that cabinets of natural history are but sketches or approximations of Nature. This is a problem ontologically given that the naturalist does not have access to Nature itself, but to these "sketches" (esquisses), which methodologically, however, are sufficient as a heuristic - sufficient "to give [the observer] an overview and point to the objects of his inquiry" (ibid., p. 229b). The materialist Diderot sounds more like Fouquet's conclusion to "Sensibilité" here - nature loves to hide, and is too complex for us to grasp as a whole - than like the rest of the empiricist montpelliérains. One can say that Diderot is both a 'vitalist' (not in the sense of being a member of the

\footnotetext{
${ }^{22}$ Outdated views on the distinct opposition between 'vitalism' and 'materialism' in eighteenth-century France still persist (e.g. Brockliss and Jones 1997, p. 430), thus it is worth noting that figures such as Ménuret and Fouquet make use of a variety of materialist arguments, for instance with respect to the soul (Wolfe and Terada 2008, § 5b); close comparison of many of the Encyclopédie articles written by Ménuret, Venel and Diderot also reveal many instances of a kind of materialist cross-pollination.

${ }^{23}$ Diderot, “Cadavres," Enc. II, p. 511a, and Éléments de physiologie, in Diderot 1975-, vol. XVII, p. 513f. - to which one can add the long passage in the article "Anatomie" where Diderot presents a deflationary case for why 'humanity' or 'inhumanity' should not be relevant concerns to the anatomist: "what is humanity if not a capacity to use our talents to assist humankind? In which case, why is it inhuman to dissect an evildoer? ... His death is as useful in an amphitheatre as on a gallows. . . And most criminals would prefer to have a fluid injected into their blood, an organ removed, or a limb amputated, to certain death" (Enc. I, pp. 409b-410a). Similar praise for anatomy and dissection, but without the militant, secularizing tone, appears in Tarin's article "Dissection" (Enc. IV, pp. 1046b-1047b).

${ }^{24}$ Riolan, “De l'anthropographie," I, ch. x, in Riolan 1628, pp. 99-100, discussed in Chamayou 2008.
} 
Montpellier Medical Faculty, but in the sense that he shares a broadly organismic framework with the montpelliérains) and that he is in favor of pathological anatomy and its atomistic, demystifying ramifications.

This favorable attitude towards pathological anatomy extends, in Diderot and at greater length in contemporaries of his such as Pierre-Louis Moreau de Maupertuis, into cold-hearted utilitarian argument which shows no qualms about human dissection (although none of them devise anything like Fichte's rather chilling formalistic case for the legitimacy of conducting medical experiments on criminals, discussed by Grégoire Chamayou in a recent study; once a death sentence has been pronounced on a criminal, he is, Fichte says, bürgerlich tot, 'dead from a civil standpoint'; hence anything that is done to the physical body of the individual does not concern his civil status - including his rights - any longer ${ }^{25}$ ). However, Diderot and the vitalists have concerns about the legitimacy of vivisections - no longer due to ethical and/or religious concerns, but to methodological and epistemological concerns that dissection and other forms of intervention into or on living bodies warp or denature the object of inquiry. This tension between a partial, non- categorical opposition to dissection and a sense that, e.g., experimentation on criminals can be justified in utilitarian terms runs beyond the Enlightenment into the nineteenth century. ${ }^{26}$

\section{Fouquet and Bordeu contra Haller}

In contrast to Ménuret and Diderot, Fouquet and Bordeu have much less of this progressivist rhetoric of how to extend the limits of our scientific knowledge through apparently immoral practices such as experimentation on the live bodies of criminals. What they share with Ménuret, however (and this makes his statements about experimenting on criminals seem more incoherent in light of the rest of his views), is a criticism of vivisection, notably as practiced by Albrecht von Haller (1708-1777), not so much for its cruelty (although this is sometimes invoked against him) as for its methodological and ontological disturbance or even destruction of the 'unity' at the heart of the functioning of a living organism.

Haller was a celebrated (or decried) vivisectionist - indeed, he was perhaps the first to design a laboratory for the collective practice of this form of experimentation. His basic

\footnotetext{
${ }^{25}$ Chamayou 2008, p. 89, citing Fichte's 1796-1797 Grundlage des Naturrechts nach Principien der Wissenschaftslehre (Foundation of Natural Right according to the Principles of the Science of Knowledge).

${ }^{26}$ Notably, Claude Bernard was a much more aggressive experimenter than the figures we are discussing, yet he retained a vitalistic impetus that is not present in someone like Haller: namely, that dissection performed on live animals ("sur le vif") is necessary to bring to light functional properties of the organism, and these properties are unique to living entities (Bernard 1865, II, ii, 2, "De la pratique expérimentale sur les êtres vivants," p. 171 and II, ii, 3, "De la vivisection," p. 173; see also Bernard 1869 and Bernard 1879, II, pp. 438445).
} 
claim for present purposes, in his article "Oeconomie animale" for the Supplément to the Encyclopédie, is that

The dissection of bodies which have died from various illnesses, sheds much light on the usage of the parts. If an organ is disturbed or destroyed, and a function is disturbed or absent in the man whose body has been opened, a probability emerges that this function is the effect of this organ: this probability becomes a kind of certainty when we find in a large number of subjects, the disturbance of structure and function combined (Haller 1778, pp. 427b-428a; emphasis mine)

As he describes at greater length concerning the property of irritability, it is only by eliminating a part of a structure that we can study its corresponding function. Haller also renders homage to Galen's experiments: to understand the larynx we have to hear the animal's screams (ibid., p. 428a)! - although he apologizes elsewhere for his experiments (Haller 1755, p. 657). The necessity of such experiments is stated rather eloquently by the physician César Legallois, who will later on be a target of Claude Bernard's irony for his scruples:

I admit that it would be barbaric to make animals suffer pointlessly, if we could reach the aims of our experiments by other means. But unfortunately this is impossible. Physiology relies heavily on experiments on living animals. There is an infinite gap between the dead animal and even the most faintly alive animal. ... How could even the wisest anatomist grasp the functioning (le jeu) of such a complicated machine - the animal body - merely by studying its organs? In order to grasp its secrets, it is not enough to observe the simultaneous activity (jeu) of all functions of the healthy animal; it is especially important to study the effects of the disturbance or elimination of a given function. The art of experimenting on living animals enables us to understand the function of a given organ, and its correlation with other functions (Legallois 1812, cit. in Rey 2000, p. 400).

When Bordeu criticizes Haller it is less because of vivisection and more of a debate over priority which becomes a rather opaque combination of scientific and almost philosophical challenges (which property is more primary? irritability or sensitivity? ${ }^{27}$ ). Fouquet, however, speaks of Haller's theory as dependent on a "horrifying experimental protocol [appareil d'expériences]," ostensibly "guided by the desire to help humankind, but leaving out no painful instrument, no source of torment for ... an infinite number of animals" ("Sensibilité," Enc. XV, p. 50b). Here is the passage in full:

Mr. de Haller first grounds his theory on a horrifying experimental protocol of his own experiments and those of some of his disciples. Guided, as he says himself, by the desire to contribute to the benefit of humankind, there is no instrument of torture, no stimulus he did not employ to vary the torments of an infinite number of animals which he subjected to this inquiries, in order to rip the truth out of them (Enc. XV, p. 50b).

Fouquet ends his article with a diatribe against Haller as vivisectionist, inspired by Robert Whytt's critique of Haller's Mémoires. ${ }^{28}$ Whytt (1714-1766) had attacked Haller's

\footnotetext{
${ }^{27}$ Bordeu 1764 in Bordeu 1818, II, p. 668, cit. Steinke 2001, p. 64.

${ }^{28}$ Vila 1998, p. 318, n. 18. Whytt is frequently described as Haller's main predecessor in the experimental study of irritability, in his 1751 Essay on the Vital and Other Involuntary Motions of Animals (with Glisson's role being
} 
'interventionism', which distorts the sensitivity of the animal by inflicting pain on it. ${ }^{29}$ As Fouquet says,

When we damage the heart of a dog after opening up its chest, the irritation of this organ will always be less [intense] than the pain caused by this opening. Moreover, if the goal is to study the irritation of the heart, shouldn't it be necessary to apply the stimulus directly within the ventricles? In that case, why should we rely on the result of such an awkward experiment? ("Sensibilité," Enc. XV, p. 51b).

Fouquet adds that the experimenter runs the risk of self-deception ("[le] risque qu'il y a de s'en imposer à soi-même dans les épreuves sur les animaux," ibid.).

An additional point in Fouquet's article which points towards a kind of minimal credo of 'holism', is that Haller's vivisection experiments also neglect - and of course destroy - the "solidarity" of parts with each other. As described in the above quotation, the idea is that once one particular area has been irritated, it draws to itself the entire sensitivity of a nervous centre, with a consequent loss in organic "solidarity" or "consensus" of the parts, as Fouquet says. "Consensus" functions like a technical term here (ibid., pp. 46a, 51a (contra Haller), 51b), similar to "conspiration," "coordination," "connection" and "sympathy." To give two examples from the later decades of the century, Diderot describes organismic unity as the "coordination of molecules" in the Éléments de physiologie (Diderot 1975-, XVII, p. 297), and Vicq d'Azyr states that when we study cadavers, "all connection, all sympathy is lost" (Vicq d'Azyr 1786, p. 2). Similarly, Ménuret in "Observateur" criticizes the physiologists who isolate functions without calling attention to their mutual action and influence, what vitalists in this period often called the "circle of action."

The vitalist critique of Hallerian vivisection does not simply rely on the opposition between observation and experiment, or an invocation of moral questions; it is also bound up with a broader 'ontological commitment' which is clearly opposed to Haller's 'enhanced mechanism'. They are different understandings of the body and embodiment - the particularities of the living body; of how to account for the unique features of organisms; more technically, the vitalist model of the living organism will not allow for "reducing specific properties to specific structures" (Steinke 2001, p. 63).

But if we look at individual actors in this story, they do not speak with one voice. Bordeu's view seems quite different from Fouquet's, even if for other reasons he was engaged in a strident polemic with Haller. In an anatomy course he gave at Montpellier, Bordeu dissected thirteen corpses, and complained of the cost. ${ }^{30}$ And one of his best

\footnotetext{
left out or marginalized, see Giglioni 2008). His reply to Haller came some years later (Whytt 1755, translated into French in 1759). Haller replied first in the Bibliothèque raisonnée (1748), cit in. Steinke 2001, p. 60; and later in his article "Sensibilité" for the Supplément, vol. 5, tome 4, pp. 776-779.

${ }^{29}$ See Bordeu, Recherches sur les maladies chroniques, in CEuvres, vol. 2, pp. 800-804; Histoire de la médecine, in op. cit., pp. 668-669, and for an extended analysis, Duchesneau 1982, pp. 171-234 (on Whytt and Haller), 361-384 (on Bordeu and Barthez).

${ }^{30}$ Bordeu 1977-1979, vol. 1, p. 105; Williams 2003, p. 76, n. 58.
} 
arguments for the uniqueness of the glands - conceptually and experimentally - was based on an experiment involving incision into the jaw of a cadaver (Bordeu 1751, in Bordeu 1818, vol. 1, p. 57). As Fouquet comments in his article "Secrétion," "M. de Bordeu demonstrates, by means of fascinating experiments and dissections, that most of the glands are located such as to prevent their being compressed in any case by the surrounding parts" (Enc. XIV, p. 874a). ${ }^{31}$ However, elsewhere in Bordeu's magnum opus, he complains that anatomists working on cadavers "lose sight of the living body" (Bordeu 1751, in Bordeu 1818, vol. 1, p. 47), which is closer to the vitalist 'vulgate' as found, e.g. in La Caze's Idée de l'homme, which as we saw earlier may have been partly co-authored by Bordeu. The latter text states unequivocally that the knowledge of the action of living beings cannot be achieved by the dissection of dead bodies; the "mechanism of life" can only be learned, in contrast, by the observation of the living body (La Caze 1755, p. 9).

\section{Conclusion}

The Montpellier Medical Faculty tries to preserve a kind of doctrinal unity as it moves into the nineteenth century (but at the expense of some of its more creative, and 'sciencefriendly' tendencies). Regarding vivisection, Jacques Lordat, the Chair in Anatomy and Physiology at Montpellier from 1813 to 1860 (and Dean of the Medical Faculty from 1819 to 130), tries in part for a synthesis. That is, instead of rejecting Haller's vivisectionist practice, he says we need to add additional types of approach to determining the appropriate functions correlated with the structure of each particular organ. In addition to Haller's trio of pathological anatomy, comparative anatomy and vivisection, Lordat says we need to consider the sum of pathological cases taken as a whole (Lavabre-Bertrand 1992, p. 186). He grants that "autopsies," as he also calls them, are worth a thousand words... (Lordat 1813, pp. 94-95), but then produces a "late vitalist" twist on this compromise:

Vivisections and experiments have lately been customarily employed in the analytic pursuit of vital properties. But if we reflect on this, we will find that this method is insufficient and often faulty. First, as these properties are only known to us through their effects, only those whose effects are promptly noticeable to our senses may be discovered thus. If we perform vivisections in order to analyze the faculties of life, what do we grasp? Mainly, that contact with certain bodies leads to a motion; that the sensorium commune perceives a painful impression; that the entire living system receives and transmits the sudden, grave effects of certain deleterious impressions (Lordat 1813, pp. 97-98; Lavabre-Bertrand 1992, p. 188).

Lordat goes on to describe in some detail what experiments cannot tell us: how nutrition assimilates ingredients in food and turns it into "a substance akin to our own," which is then distributed in our body to increase its power or repair its losses; how vital fluids are modified

\footnotetext{
${ }^{31}$ For further description of Bordeu's experiments on glands, including in the jaw, see Williams 2003, p. 155. Boury comments rather critically on these experiments that they are more like anatomical demonstrations than experiments with rigorous protocols (Boury 2004, p. 87), which seems perhaps too strict or restrictive a definition of experiment.
} 
so as to transmit contagious diseases; how humours can be made to "depart" from one place to another; how heterogeneous molecules stay together and compose one "animal" body, which resists the action of "dissolving agents," and so on (ibid.). That is, autopsies or vivisections do not tell us anything relevant about physiology, biochemistry and particularly homeostatic processes.

In sum, the Montpellier vitalists do not have a univocal, uniformly hostile position towards pathological anatomy. Much like Ménuret, La Caze says that we have little to learn from the "opening-up of corpses" if we not have studied the disease before the death of the patient (La Caze 1755, p. 9). This wavering persists into the waning years of what the history of medicine chooses to call vitalism (and which internally is more of a battleground, in the sense that each new figure like Bichat, then Bernard will call the previous generation 'vitalists' and argue that his own work which definitely adds new features to the uniqueness of organic beings, is somehow scientific rather than metaphysical). Thus Bichat, writing in the late 1790s and very early 1800s before his untimely death, says that not only the anatomist, but also the physiologist and the physician, cannot dispense with the combination of dissection, physiological experimentation, patient treatment and post mortem autopsies, ${ }^{32}$ but in his best-known work, the Recherches physiologiques sur la vie et la mort, he returns to the more predictable identification between pathological or 'cadaverous' anatomy, and death or stasis. Yet his criticisms of vivisection are only on $a$ posteriori grounds, without a normative dimension ("we must beware of making hasty pronouncements about vital forces based on experiments" ${ }^{33}$ ), and he conducted many respiration experiments, influenced by Lavoisier. Unlike Haller who dissolved the distinction between anatomy and physiology, at least in the sense of static structure versus animated function (his famous definition of physiology in the opening lines of the Primae linae physiologiae is as 'animated anatomy', animata anatome), these later vitalists still insist on an opposition between the skeleton and the living body: "Anatomy alone is, so to speak, merely the skeleton of science; Physiology adds movement to it. The latter is the study of life, while the former is but the study of death." ${ }^{34}$

This may make the combination of biomedical holism and advocating experimentation on criminals less confusing (as in Ménuret's article "Observation"). It may seem obvious but I think it bears saying, that one can have a holistic or organismic understanding of the functioning of the animal economy without automatically being an anti-vivisectionist. In that sense Bastholm is wrong, in his classic history of physiology, when he says: "it is very interesting to see how the idea of a vitalistic principle will mislead people

\footnotetext{
32 Bichat, Traité d'anatomie descriptive (1801-1803), 1834, p. 10, cit. in Rey 1997, p. 124. It is just this sort of wavering or consideration of the pros and cons of dissection and conversely, a holistic sense of the irreducible totality of the living organism, which is entirely absent or even occluded by 'pro-mechanistic' histories of physiology such as Schiller 1978.

${ }^{33}$ Discours sur l'étude de la physiologie, pub. in 1911, p. iv, cit. in Rey 2000, p. 365.

${ }^{34}$ Vicq d'Azyr, an XIII [1805], p. 37.
} 
into ignoring anatomy" (Bastholm 1950, p. 228). From Bordeu on the glands to Ménuret on the animal economy (and Fouquet on the pulse, admittedly a less strictly anatomical affair), such a statement is not correct; but then again, none of these vitalists seems to believe in a "vitalistic principle." They criticize mechanism and are reticent about vivisection without appealing to the sacrosanct status of some special 'vital force' distinct from the rest of the material universe, which, as we saw above, makes their view that much closer to Diderot's 'vital materialism'. If they insist on the uniqueness of living beings, it is rather in the form of a 'weak vitalism', or what I have described elsewhere as 'functional' rather than 'substantival' vitalism (Wolfe and Terada 2008; Wolfe 2011). This hostility to intervention, which is roughly synonymous with mechanism in their eyes, is never as categorical as, say, Kant's notorious assertion that there will "never be a Newton of a blade of grass," that all organic beings, even blades of grass, are and will remain inaccessible to Newtonian explanations (which here stand for mechanical explanations in general).

I have also mentioned their 'empiricism', which they associate with the tradition of "expectant medicine" (e.g. Ménuret, "Observation," Enc. XI, p. 315b). In that sense, it is a specifically medical empiricism, which I have described elsewhere as 'embodied empiricism'. ${ }^{36}$ Ménuret, in the article "Observateur," praises Sydenham the observer and criticizes Boerhaave the experimenter because he became fixated on his own categories of definition of disease, rather than on the (empirical) complexity of what diseases are actually like; on the regularity of categories rather than the "irregularity observed at the patient's bedside" (Enc. XI, p. 313a). That Nature is more complex than the mechanist's categories is somewhat reminiscent of Diderot's idea of "cabinets of natural history," artificial constructs which we need in order to grasp the complexity of living Nature. But Ménuret's objection is really in two parts: the experimental, mechanistic medicine of Boerhaave and Haller (a) is too much of a theory ("Observation," Enc. IX, pp. 314-315), and (b) is too interventionist (ibid., pp. 316a-b). Sometimes, instead of Sydenham versus Boerhaave, the opposition is between Hippocrates and Galen: "Hippocrates was the first and best of the observer physicians" (p. 316a).

From Ménuret and Diderot to Bichat, Magendie and Bernard, the vivisectionist is forced to recognize the irreducibility of living, embodied agents (Bernard 1868; Coleman 1985). If we track the combination of organismic concepts and experimental practice from Bordeu et al. into the nineteenth century, we see the insistence on the uniqueness of organisms is a constant, but the experimental practice shifts. We might speak of a spectrum of vitalist views, as the opposition between observation and experiment (particularly targeting 'mechanistic' medicine) comes in different forms. It can be employed in any combination of epistemological, methodological and ontological objections to dissection

\footnotetext{
${ }^{35}$ Kant 1987, § 75, pp. 282-283.

${ }^{36}$ On embodied empiricism, see Wolfe and Gal, eds., 2010; on embodiment in early modern materialist thought, see Wolfe, forthcoming.
} 
and/or vivisection (clearcut distinctions between these are rarely made here); but also in arguments which do not object to any of the above.

Leaving aside Ménuret's rather unique call for experimentation on criminals (unique amongst vitalists, at least), their concern seems to be mainly with either the status of living beings in general (their 'ontological status'), or the most appropriate ways to gain knowledge about them (a concern in which the distinction between anatomy and physiology is blurred). In the name of what do the vitalists reject vivisection then? A sense of organic unity variously termed connection, cohesion, consensus, coordination, sympathy... - which is also a weak sense of the irreducibility of embodiment. Just as the montpelliérains can insist on the properties specific to living beings without invoking any vital 'essence', force or principle, conversely, the demystifying practice of vivisection opens onto the phenomena pertaining to living beings (Métraux 2004, pp. 46-47). Vivisection becomes an a posteriori proof of vitalism! 


\section{References}

Aït-Touati, Frédérique. forthcoming 2011. Fictions of the Cosmos. Science and Literature in the Seventeenth Century. Chicago: University of Chicago Press.

Bacon, Francis. 1857-1874. The Works of Francis Bacon, eds. James Spedding, Robert Leslie Ellis and Douglas Denon Heath, 14 vols. London: Longman \& Co.

Barthez, Paul-Joseph. 1806. Nouveaux éléments de la science de l'homme, $2^{\text {nd }}$ revised edition, 2 vols. (1st edition 1778). Paris: Goujon \& Brunot.

Barthez, Paul-Joseph. , 1858. Nouveaux éléments de la science de l'homme, $3^{\mathrm{d}}$ revised and expanded edition, 2 vols. Paris: Germer Baillière.

Bastholm, Eyvind. 1950. The History of Muscle Physiology from the Natural Philosophers to Albrecht von Haller (Acta Historica Scientiarum Naturalium et Medicinalium, vol. VII). Copenhagen:

Munksgaard.

Bernard, Claude. 1865. Introduction à l'étude de la médecine expérimentale. Paris: J.B. Baillière \& Fils.

Bernard, Claude. 1869. Histoire de l'expérimentation physiologique - l'art d'expérimenter sur les êtres vivants. Revue des cours scientifiques de la France et de l'étranger, $6^{\mathrm{e}}$ année, 194-200. Paris: Germer Baillière.

Bernard, Claude. 1879. Leçons sur les phénomènes de la vie communs aux animaux et aux végétaux, tome II. Paris: Germer Baillière.

Bloch Oscar and Wartburg, Walther von. 1954. Dictionnaire étymologique de la langue française. Paris: Larousse.

Bordeu, Théophile de. 1751. Recherches anatomiques sur la position des glandes et leur action. Paris: Quillau père.

Bordeu, Théophile de. 1754. Crise (Médecine). Encyclopédie, eds. D. Diderot and J. D'Alembert, IV: 471-489. Paris: Briasson.

Bordeu, Théophile de. 1764. Recherches sur quelques points d'histoire de la médecine. Paris: Cailleau.

Bordeu, Théophile de. 1818. CEuvres complètes, précédées d'une Notice sur sa vie et ses ouvrages par Monsieur le Chevalier de Richerand, 2 vols. Paris: Caille et Ravier.

Bordeu, Théophile de. 1977-1979. Correspondance, 4 vols., ed. Martha Fletcher, w. Nadine Labbé and Aloys de Laforcade. Montpellier : CNRS/Université Paul-Valéry, Groupe de recherche sur les Textes Modernes.

Boury, Dominique. 2004. La philosophie médicale de Théophile de Bordeu (1722-1776). Paris: Honoré Champion.

Brockliss, Laurence and Jones, Colin. 1997. The Medical World of Early Modern France. Oxford: Clarendon Press.

Cavendish, Margaret. 1656. Natures Pictures drawn by Fancies Pencil to the Life. London: J. Martin and J. Allestrye. 
Cavendish, Margaret. 1666. Observations upon Experimental Philosophy. London: A. Maxwell.

Chamayou, Grégoire. 2008. Les corps vils: Expérimenter sur les êtres humains aux XVIII et XIX siècles. Paris: Les Empêcheurs de Penser en Rond / La Découverte.

Coleman, William. 1985. The cognitive basis of the discipline: Claude Bernard on physiology. Isis 76: 49-70

Daston, Lorraine. 2011. The Empire of Observation, 1600-1800. In Histories of Scientific Observation, eds. Lorraine Daston and Elizabeth Lunbeck, pp. 81-113. Chicago: University of Chicago Press.

Dear, Peter. 2006. The Meanings of Experience. In The Cambridge History of Science, vol. 3: Early Modern Science, eds. K. Park \& L. Daston, 106-131. Cambridge: Cambridge University Press.

Descartes, René. 1964-1976. CEuvres, eds. C. Adam and P. Tannery, 11 vols. Paris: Vrin (cited as AT followed by volume and page number).

Diderot, Denis. 1975-. CEuvres complètes, eds. H. Dieckmann, J. Proust, J. Varloot. Paris: Hermann.

Diderot, Denis and D'Alembert, Jean le Rond, eds. 1765. Encyclopédie ou Dictionnaire raisonné des sciences, des arts et des métiers... Paris: Briasson. Online at University of Chicago, ARTFL Encyclopédie Projet, ed. Robert Morrissey, http://encyclopedie.uchicago.edu/

Gilad, David. 2010. The Epistemology of Light and Colors in Goethe's era Germany. PhD, University of Sydney, Unit for the History and Philosophy of Science.

Goethe, Johann Wolfgang von. 1988. Scientific Studies, ed. \& trans. Douglas Miller. The Collected Works, Vol. 12. New York: Suhrkamp / Princeton: Princeton University Press.

Guerrini, Anita. 1989. The Ethics of Animal Experimentation in Seventeenth-Century England. Journal of The History of Ideas 50(3): 391-407

Haller, Albrecht von. 1755. A Dissertation on the Sensible and Irritable Parts of Animals. London: J. Nourse.

Haller, Albrecht von. 1778. Oeconomie Animale. In Encyclopédie ou dictionnaire raisonné des sciences, des arts et des métiers, nouvelle édition, vol. 23: 427a-429b. Geneva: Pellet.

Kant, Immanuel. 1987. Critique of Judgment, trans. W. Pluhar. Indianapolis: Hackett.

Kass, Leon. 1999. The Hungry Soul: Eating and the Perfecting of Our Nature. Chicago: University of Chicago Press.

Lavabre-Bertrand, Thierry. 1992. La philosophie médicale de l'école de Montpellier au XIX siècle. Thèse de doctorat. Paris: École Pratique des Hautes Études, IV Section.

Legallois, Julien Jean César. 1812. Expériences sur le principe de vie. Paris: d’Hautel.

Lower, Richard. 1932. Tractatus de Corde [London, 1669], trans. K.J. Franklin in R.T. Gunther, Early Science in Oxford, Vol. IX. Oxford: Oxford University Press. 
Lordat, Jacques. 1813. Conseils sur la manière d'étudier la physiologie de l'homme. Montpellier:

Delmas.

Maehle, Andreas H. and Tröhler, Ulrich. 1987. Animal Experimentation from Antiquity to the End of the Eighteenth Century: Attitudes and Arguments. In Vivisection in Historical Perspective, ed. Nicolaas A. Rupke, pp. 14-47. London: Croom Helm.

Merchant, Carolyn. 1980. The Death of Nature: Women, Ecology, and the Scientific Revolution. San Francisco: Harper and Row.

Métraux, Alexandre. 2004. 1064332 atomes et un cercle de vie. Multitudes 16: 41-47.

Pesic, Peter. 1999. Wrestling with Proteus: Francis Bacon and the 'Torture' of Nature. Isis 90: 81-94

Raven, C.E. 1942. John Ray Naturalist: His Life and Works. Cambridge: Cambridge University Press.

Rey, Roselyne. 1997. L'âme, le corps et le vivant. In Histoire de la pensée médicale en Occident, vol. 2: De la Renaissance aux Lumières, ed. M. Grmek, pp. 117-156. Paris: Seuil.

Riolan, Jean. 1628. Les œuvres anatomiques de Jean Riolan, vol. 1. Paris: Denys Moreau.

Roederer, Johann Georg. 1765 (orig. 1753). Elemens de l'Art des Accouchemens: Augmentes des Observations sur les Accouchemens Laborieux, a l'Usage des Etudians en Medecine et en Chirurgie. Paris: Didot Le Jeune.

Salomon-Bayet, Claire. 1978. L'institution de la science et l'expérience du vivant: méthode et expérience à l'Académie Royale des Sciences, 1666-1793. Paris: Flammarion.

Salter, Alan. 2010. William Harvey. A Study in Empiricism. PhD, University of Sydney, Unit for History and Philosophy of Science.

Salter, Alan \& Wolfe, Charles T. 2009. Empiricism contra Experiment: Harvey, Locke and the Revisionist View of Experimental Philosophy. Bulletin de la Société d'histoire et d'épistémologie des sciences de la vie 16(2): 113-140

Sarasohn, Lisa T. 1984. A Science Turned Upside down: Feminism and the Natural Philosophy of Margaret Cavendish. Huntington Library Quarterly 47(4): 289-307

Sarasohn, Lisa T. 2010. The Natural Philosophy of Margaret Cavendish: Reason and Fancy during the Scientific Revolution. Baltimore: Johns Hopkins University Press.

Schiller, Joseph. 1978. La notion d'organisation dans l'histoire de la biologie. Paris: Maloine.

Semler, Liam E. 2010. The Man:Beasts Debate in Margaret Cavendish's Early Works. Paper presented at the 'Rise of Empiricism' conference, University of Sydney, Department of Philosophy.

Staden, Heinrich von. 1975. Experiment and Experience in Hellenistic Medicine. Bull. Inst. Class. Stud. 22: 178-199

Steinke, Hubert. 2001. Haller's Concepts of Irritability and Sensibility and their Reception in France. In Mécanisme et vitalisme, ed. M. Saad, La lettre de la Maison française d'Oxford 14: 37-69 
Steinke, Hubert. 2005. Irritating Concepts: Haller's Concept and the European Controversy on Irritability and Sensibility, 1750-1790. Amsterdam: Rodopi.

Vicq d'Azyr, Félix. 1786. Traité d'anatomie et de physiologie avec des planches coloriées représentant au naturel les divers organes de l'Homme et des Animaux, 2 vols. Paris: Didot l'aîné.

Vicq d'Azyr, Félix. an XIII [1805]. Plan d'un cours d'anatomie et de physiologie, in CEuvres, éd. Moreau de la Sarthe, vol. 4. Paris: L. Duprat-Duverger.

Vila, Anne C. 1998. Enlightenment and Pathology. Sensibility in the Literature and Medicine of Eighteenth-Century France. Baltimore: Johns Hopkins University Press.

Walmsley, J.C. 2008. Sydenham and the Development of Locke's Natural Philosophy. British Journal for the History of Philosophy 16(1): 65-83.

Webster, Charles. 1969. Henry More and Descartes: Some New Sources. British Journal for the History of Science 4(16): 359-377

Williams, Elizabeth A. 2003. A Cultural History of Medical Vitalism in Enlightenment Montpellier. Burlington: Ashgate.

Williams, Elizabeth A. 2008. Of Two Lives One? Jean-Charles-Marguerite Guillaume Grimaud and the Question of Holism in Vitalist Medicine. Science in Context 21(4): 593-613.

Whytt, Robert. 1755. Observations on the Sensibility and Irritability of the Parts of Man and Other Animals: occasioned by Dr. Haller's late Treatise on these Subjects. In Physiological Essays. Edinburgh: Hamilton, Balfour \& Neill.

Whytt, Robert. 1759. Essais physiologiques, contenant : I. des Recherches sur les causes du mouvement des fluides dans les très petits vaisseaux des animaux; Il. des Observations sur la sensibilité et sur l'irritabilité des parties du corps animal à l'occasion du Mémoire de M. Haller sur ce sujet, trans. Thébault. Paris: les frères Estienne.

Wolfe, Charles T. 2009. 'Cabinet d'Histoire Naturelle', or: The Interplay of Nature and Artifice in Diderot's Naturalism. Perspectives on Science 17(1): 58-77

Wolfe, Charles T. 2011. From substantival to functional vitalism and beyond, or from Stahlian animas to Canguilhemian attitudes. Eidos 14: 212-235

Wolfe, Charles T. forthcoming. Forms of Materialist Embodiment. In Bodies of Knowledge: Anatomy, Complexity and the Invention of Organizational Systems, 1500-1850, eds. Matthew Landers and Brian Muñoz. London: Pickering and Chatto.

Wolfe, Charles T. and Terada, Motoichi. 2008. The Animal Economy as Object and Program in Montpellier Vitalism. Science in Context 21(4): 537-579.

Wolfe, Charles T. and Gal, Ofer, eds. 2010. The Body as Object and Instrument of Knowledge. Embodied Empiricism in Early Modern Science. Dordrecht: Springer. 